\title{
IMPROVEMENT METHOD OF CALCULATION REINFORCED CONCRETE BEAMS ON THE SHEAR STRENGTHENED FRCM SYSTEM
}

doi: 10.2478/czoto-2020-0026

Date of submission of the article to the Editor: 29/11/2019

Date of acceptance of the article by the Editor: 15/01/2020

Zinoviy Blikharskyy ${ }^{1}$ - orcid id: 0000-0002-4823-6405

Pavlo Vegera ${ }^{1}$ - orcid id: 0000-0002-3437-1825

Rostyslav Vashkevych ${ }^{1}$ - orcid id: 0000-0001-9962-7580

Roman Khmil ${ }^{1}$ - orcid id: 0000-0001-7578-8750

1'Lviv Polytechnic National University, Ukraine, Pavlo.I.Vehera@lpnu.ua

Abstract: Determination of shear-load-bearing capacity of reinforced concrete beams (according to the current normative documents), comprises particular recommended values, which do not depend on the parameters of the sample or load. This article describes the methodology for determination the shear strength with suggestions for calculation the coefficient $C_{R d, c}$ and compressed element tilt angle $\theta$ while reinforced concrete elements ' calculation with the use of "truss model". In order to confirm the methodology 4 reinforced concrete beams were tested. Tests were performed in order to investigate each particular inclined section separately. Variable parameter was the relative shear span $a / d$, with its values $a / d=2, a / d=1,5$ and $a / d=1$. Another parameter was the usage of composite strengthening system, made for relative shear span $a l d=2$. Samples were tested as single-span beams subjected to short-term loading. The calculation with the use only the values, given in norms showed significant divergence of results. Using the refined parameter values provided the convergence of results within $16-29 \%$ toward overestimation of the experimental data. The composite reinforcement system calculation showed the overestimation of $23 \%$, which is within the same limits as for the control samples.

Keywords: reinforced concrete beam, shear, shear span, FRCM strengthening, calculation

\section{INTRODUCTION}

Reinforced concrete is one of the most widely used building materials in Ukraine and worldwide. Its widespread usage is caused by the materials` cheapness, the simplicity of structures` manufacturing and complex elements` assembling. However, during operation, reinforced concrete structures are subjected to damages and defects that reduce its bearing capacity and durability (Blikharskyy et al., 2019; Lobodanov et al., 2020). Especially difficult are cases of structures, manufactured using pre-stressed reinforcement or the combination of various reinforcement types (Bobalo et al., 2020; 
Bobalo et al., 2018). Therefore, over time it is necessary increase load-bearing capacity or restore reinforced concrete elements through reconstruction or strengthening. The most common methods are reinforcement by arrangement of reinforced concrete jacket (Krainskyi et al., 2020). However, this method is time-consuming and increases the total structure weight. Composite strengthening systems are more modern and effective (Selejdak et al., 2020). They are based on the usage of high-strength materials containing carbon or P.B.O, fibers. Usage of such materials is relevant because of their high strength, low self-weight and small geometric dimensions. Such reinforcement systems are widely used in bended reinforced concrete elements (Ferrari and de Hanai 2012; Rossini et al., 2019). Less common and more complicated is the case of strengthening of reinforced concrete beams subjected to shear force. Such research implementation is difficult because of both the complex stress-strain state of inclined elements, as well as the introduction of such additional factor as the composite reinforcement. Therefore, this article is focused on the methodology of calculating of reinforced concrete beams with and without FRCM-system strengthening.

\section{METHODOLOGY OF RESEARCH}

Valid normative documents (DBN, 2011; Eurocode 2, 2004) regulate calculation of inclined sections according to "truss model". The bearing capacity of the cross-section in the zone of shear force impact with no transverse reinforcement is considered as the concrete shear strength at $45^{\circ}$ angle.

The strength of reinforced concrete beams' inclined sections is considered as the strength condition:

$$
V_{E d} \leq V_{R d, c}
$$

where $V_{E d}=Q$ - design value of shear force due to external load. The design value of shear force, which could be received by elements cross-section without transverse reinforcement, pre-stressed longitudinal reinforcement or axial force, according to norms (DBN, 2011; Eurocode 2, 2004), could be determined through equation:

$$
V_{R d, c 1}=\frac{\left[C_{R d, c} \cdot k \cdot\left(100 \cdot \rho_{1} \cdot f_{c k}\right)^{1 / 3}\right] \cdot b_{w} \cdot d}{\beta}
$$

However, if the calculated value is less than:

$$
V_{R d, c 2}=v_{\min } \cdot b_{w} \cdot d
$$

where $\mathrm{C}_{R d, c}$ - concrete shear strength (Amadio et al., 2011), in normative documents (DSTU, 2011; Eurocode 2, 2004) is recommended to assume this value equal to 0.18 ; $k=1+\sqrt{200 / d}$ - the coefficient of beam height influence; $\rho_{1}=\frac{A_{s l}}{b_{w} \cdot d}-$ the reinforcement coefficient; $A_{s l}$ - the area of reinforcement, subjected to tension, $\mathrm{mm}^{2} ; f_{c k}$ - the characteristic value of concrete compressive strength at the age of 28 days, MPa; $b_{w}, d$ -the smallest cross-section weight in tensed zone and effective cross-section height respectively, $\mathrm{mm} ; v_{\min }=0.035 \cdot k^{3 / 2} \cdot f_{c k}^{1 / 2}$ - the minimal value of shear strength, which could lead to destruction due to reaching the yield strength point in longitudinal reinforcement, MPa.

Longitudinal reinforcement was taken into account only if it was continued at a distance of $l_{b d}$ beyond for the projection of the calculated cross section at an angle of $45^{\circ}$, where $l_{b d}$ is the minimum required length of anchorage of the longitudinal reinforcement (Figure 1). 


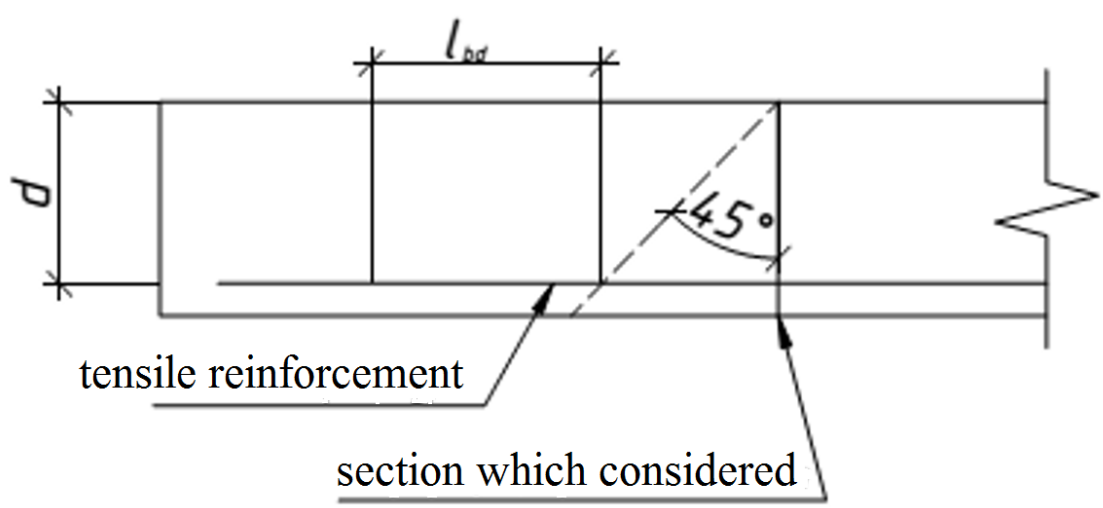

Fig. 1. The model of factors' influence on the concrete inclined cross-section strength Source: (DSTU, 2011; Eurocode 2, 2004)

Coefficient $\beta$, which is equal to $\beta=\alpha_{v} /(2 \cdot d)$ is considered in the case of load application above within $0.5 \cdot d \leq \alpha_{v} \leq 2 \cdot d$ (Fig. 2), as the reduction it into account by $\mathrm{n}$ factor for shear force $V_{E d}$. In this case it is recommended to introduce it into the concrete bearing capacity $V_{R d}$ calculation apparatus by dividing the calculated bearing capacity into this coefficient.

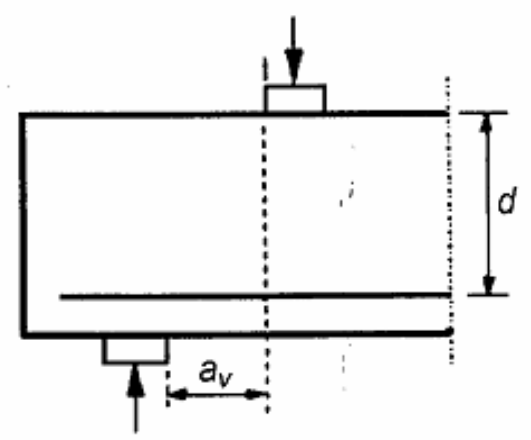

Fig. 2. Load application for coefficient $\beta$

Source: (DSTU, 2011; Eurocode 2, 2004)

In the case of taking into account coefficient $\beta$ the following condition has to be fulfilled:

$$
V_{E d} \leq 0.5 \cdot b_{w} \cdot d \cdot v \cdot f_{c d}
$$

where $f_{c d}$ - the design value of concrete compressive strength, MPa; $v$ - reduction factor for the concrete shear strength, taking into account the existing cracks. It is recommended to calculate this coefficient through the equation (DSTU, 2011; Eurocode 2, 2004):

$$
v=0.6 \cdot\left[1-\frac{f_{c k}}{250}\right]
$$

In this calculation methodology there are no instructions for coefficient $\mathrm{C}_{R d, c}$ estimation. It is recommended to use the constant value of $0.18 \mathrm{MPa}$ in all cases. In order to determine the concrete shear strength influence on the inclined cross sections' bearing capacity it could be recommended to use formula, given in European norms, published in 1994 and which takes into consideration change of concrete shear strength due to tension (Eurocode 2, 1994): 


$$
C_{R d, c}=\tau_{R d}=0.25 \cdot f_{c t k \cdot 0.005}
$$

The major concrete characteristic is its compressive strength, therefore in equation (6) will be proposed the transition from tensile strength to compressive strength according to formulas, given in above cited norms:

$$
\begin{gathered}
f_{c t k \cdot 0.005}=0.7 \cdot f_{c t m} \\
f_{c t m}=0.3 \cdot f_{c k}^{2 / 3}
\end{gathered}
$$

As the result, the following equation for concrete shear strength is obtained:

$$
C_{R d, c}=0.0525 \cdot \sqrt[3]{f_{c k}^{2}}
$$

Calculation of the reinforced concrete beams, strengthened by composite system will be conducted on the basis condition that cross section and reinforcement system perceive all stress in the areas close to supports:

$$
V_{R d}=V_{R d, c}+V_{R d . s}^{a d d}
$$

For further bearing capacity calculation following assumptions in strengthened inclined cross sections performance are taken into account:

- for strengthened inclined section the plane sections ' hypothesis is fair;

- the composite reinforcement performs itself as the additional external reinforcement;

- reinforcement system works compatibly with concrete in inclined section;

Therefore, the external composite reinforcement is introduced in truss calculation model as the truss elements, subjected to tension.

If all the assumptions are fulfilled it could be recommended to calculate the strengthening element bearing capacity as for the transverse reinforcement, therefore for reinforcement system bearing capacity calculation will be used the formula from norms (DSTU, 2011; Eurocode 2, 2004) for determination of shear bearing capacity due to armature, considering the composite textile:

$$
V_{R d . s}^{a d d}=\frac{A_{s w}^{a d d}}{s} \cdot z \cdot f_{y w d}^{a d d} \cdot \cot \theta
$$

where $A_{f w}$ - the external reinforcement cross section area, $\mathrm{mm}^{2} ; s_{f}$ - reinforcement elements`spacing, $\mathrm{mm}$.

For determination of additional reinforcement bearing capacity the compressed element tilt angle was $21.8^{\circ}$, according to experimental data (Fig. 3). Such value of the angle $\theta$ corresponds to the maximum value $\cot \theta=2.5$. 


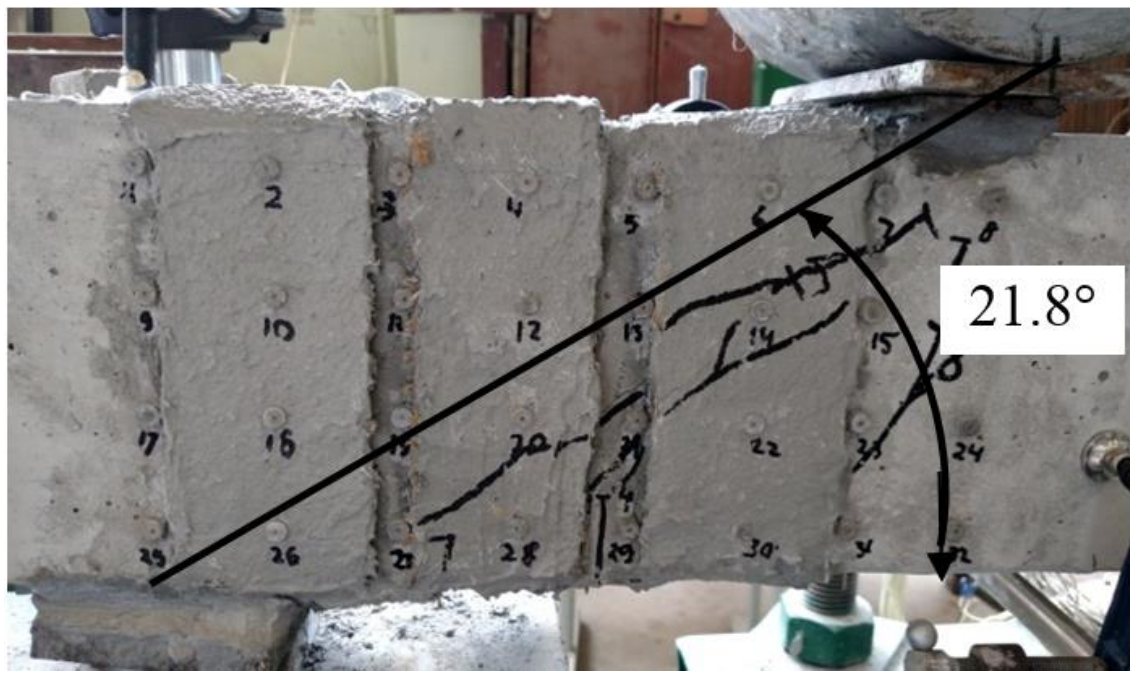

Fig. 3. The tilt angle of compressed element in strengthened sample

The design composite reinforcement strength was calculated by formula (12) according to recommendations (Triantafillou et al., 2001):

$$
f_{y w d}^{a d d}=k \cdot \varepsilon_{f d, e} \cdot E_{f u d}=k \cdot \frac{\varepsilon_{f k, e}}{\gamma_{f}} \cdot 0.4 \cdot E_{f u k}
$$

where $\varepsilon_{f d, e}$ - the limit strain design value for composite reinforcement; $\varepsilon_{f k, e}=\frac{\varepsilon_{f, e}}{\gamma_{f}}-$ the characteristic value of composite reinforcement limit strain; $\gamma_{f}=1.3$ - safety factor due to the material according to recommendations FIB, which is taken in the case of textile slippage possibility or as $\gamma_{f}=1.35$ in the case of possible textile rupture (if it is impossible all the above cited conditions to be fulfilled, than the coefficient is taken equal to $1) ; k=0.8$ - the reduction factor for transition from tensile strength to shear strength, given in valid norms (DSTU, 2011; Eurocode 2, 2004) FIB's recommendations (Triantafillou T.et al 2001); $E_{f u d}$ - the design value of composite material elasticity module, assumed on the $40 \%$ level of the characteristic value.

According to recommendations FIB (Triantafillou T.et al 2001) consistent work of the concrete and reinforcement elements could be reached only at such reduction of the composite material elasticity module.

According to this methodology was conducted the calculation of RC beams' shear bearing capacity without transverse reinforcement, but with external composite FRCM- system reinforcement.

\section{EXPERIMENTAL DATA}

The test samples had cross section dimensions of $200 \times 100 \mathrm{~mm}$ and effective span of $1900 \mathrm{~mm}$. Reinforcement was made as $2 \varnothing 18 \mathrm{~mm}$ A500C - tensed steel bars and $2 \varnothing 10$ A500C - compressed steel bars. In the zones, close to supports, there is no transverse reinforcement. For strengthening was used the composite system FRCM, applied as the tapes of $70 \mathrm{~mm}$ weight with spacing of $100 \mathrm{~mm}$. Such strengthening type was chosen in order to monitor and fix the process of inclined crack disclosure in concrete. Generally, 4 samples were tested. The variable parameter was the relative shear span $\mathrm{a} / \mathrm{d}$, which was taken equal to $\mathrm{a} / \mathrm{d}=2, \mathrm{a} / \mathrm{d}=1.5$ and $\mathrm{a} / \mathrm{d}=1$, for the last sample was used the composite system strengthening with the relative shear span of $a / d=2$. More details 
on the test samples construction (Blikharskyy et al., 2020) and experimental methodology could be founded in work (Vegera et al., 2015).

According to the experimental results all the samples experienced collapse due to inclined sections' bearing capacity exhaustion (Table1).

Table 1

Experimental data for $\mathrm{RC}$ beams

\begin{tabular}{|c|c|c|c|c|c|c|c|}
\hline $\begin{array}{l}\text { Beam } \\
\text { code }\end{array}$ & $\begin{array}{l}\text { № of the } \\
\text { cross } \\
\text { section }\end{array}$ & $\begin{array}{c}\text { Cross } \\
\text { section } \\
\text { bxh mm }\end{array}$ & $\begin{array}{c}\text { Effective } \\
\text { beam } \\
\text { span } \\
\mathrm{I}_{0} \mathrm{~mm}\end{array}$ & $\begin{array}{c}\text { Shear } \\
\text { span } \\
\text { a/d }\end{array}$ & $\begin{array}{l}\text { Shear load } \\
\text { bearing } \\
\text { capacity of } \\
\text { RC beam } \\
V_{E d}^{\text {exp }}, \mathbf{k N}\end{array}$ & $\begin{array}{l}\text { The aver- } \\
\text { age value } \\
\text { of bear- } \\
\text { ing ca- } \\
\text { pacity, } \\
V_{E d}^{\exp }, \mathbf{k N}\end{array}$ & $\begin{array}{c}\text { The in- } \\
\text { crease of } \\
\text { bearing } \\
\text { capacity } \\
\frac{V_{e d}^{\text {streng }}}{V_{e d}^{\text {unstreng }}}\end{array}$ \\
\hline \multirow{2}{*}{ BO 1.1} & Б3 1.1.1 & \multirow{2}{*}{$201 \times 101$} & 1900 & \multirow{2}{*}{2} & 97 & \multirow{2}{*}{95} & \multirow{2}{*}{ - } \\
\hline & Б3 1.1.2 & & 1650 & & 93 & & \\
\hline \multirow{2}{*}{ BO 1.2} & Б3 1.2.1 & \multirow{2}{*}{$199 \times 98$} & 1900 & \multirow{2}{*}{1.5} & 139 & \multirow{2}{*}{140.5} & \multirow{2}{*}{1.48} \\
\hline & Б3 1.2 .2 & & 1750 & & 142 & & \\
\hline \multirow{2}{*}{ BO 1.3} & Б3 1.3.1 & \multirow{2}{*}{$202 \times 98$} & 1900 & \multirow{2}{*}{1} & 192 & \multirow{2}{*}{198} & \multirow{2}{*}{2.08} \\
\hline & Б3 1.3.2 & & 1650 & & 204 & & \\
\hline \multirow{2}{*}{ BSC 1.4} & БПК 1.4.1 & \multirow{2}{*}{$199 \times 100$} & 1900 & \multirow{2}{*}{2} & 130 & \multirow{2}{*}{137.5} & \multirow{2}{*}{1.45} \\
\hline & БПК 1.4.2 & & 1650 & & 145 & & \\
\hline
\end{tabular}

According to experimental results was fixed the increase in inclined sections ' bearing capacity in 1.48 times with simultaneous decrease in relative shear span from $a / d=2$ to $\mathrm{a} / \mathrm{d}=1.5$ and at $\mathrm{a} / \mathrm{d}=1$ the bearing capacity increase accounted 2.08 times. Such an effect is characteristic at the reduction of the relative shear span as the result of increase in compressive stresses, perceived by concrete within the cross section.

The maximum effect of bearing capacity increase was about $45 \%$. The strengthening effect is similar to the increase of inclined sections bearing capacity at reduction or relative shear span from $\mathrm{a} / \mathrm{d}=2$ to $\mathrm{a} / \mathrm{d}=1.5$.

\section{RESULTS}

The calculation was conducted using the (2) and values, recommended in norms (DBN, 2011; Eurocode 2, 2004). For the purpose of comparison and testing was proposed the value of $\mathrm{C}_{R d, c}$, determined by formula (9) and was conducted the additional calculation with the use of equation (2). Calculation results are given in the table 2.

Obtained data make it possible to conclude that calculation only with the use of norms recommendations provides overstated values of shear-load bearing capacity for $\mathrm{RC}$ beams. However, the use of values $\mathrm{C}_{R d, c}$, recommended in previous European norns (Eurocode 2, 1994), the accuracy of results was about 16-29\% towards overstating of experimental data. This provides reliable results for determination of shear-load bearing capacity for $\mathrm{RC}$ beams without transverse reinforcement. 
Table 2

Results of test samples bearing capacity

\begin{tabular}{|c|c|c|c|c|c|c|}
\hline \multirow[t]{2}{*}{$\begin{array}{l}\text { Beam } \\
\text { code }\end{array}$} & \multirow[t]{2}{*}{$\begin{array}{c}\text { Shear } \\
\text { span a/d }\end{array}$} & \multirow{2}{*}{$\begin{array}{c}\text { Experi- } \\
\text { mental } \\
\text { shear } \\
\text { strength, } \\
V_{E d}(Q), k N\end{array}$} & \multicolumn{2}{|c|}{$\begin{array}{c}\text { Theoretical shear } \\
\text { strength according } \\
\text { to DSTU. B.V. 2.6- } \\
156: 2010\end{array}$} & \multicolumn{2}{|c|}{$\begin{array}{l}\text { Theoretical shear } \\
\text { strength with } C_{R d, c}, \\
\text { according to Euro } \\
\text { code } 2\end{array}$} \\
\hline & & & $\begin{array}{c}V_{R d, c 1,} \\
\mathbf{k N}\end{array}$ & $\frac{V_{E d}}{V_{R d, c 1}}$ & $\begin{array}{c}V_{R d, c 1,} \\
\text { kN }\end{array}$ & $\frac{V_{E d}}{V_{R d, c 2}}$ \\
\hline BO 1.1 & 2 & 95.0 & 32.8 & 2.89 & 81.6 & 1.16 \\
\hline BO 1.2 & 1,5 & 140.5 & 43.7 & 3.22 & 108.8 & 1.29 \\
\hline BO 1.3 & 1 & 198.0 & 65.5 & 3.02 & 163.2 & 1.21 \\
\hline
\end{tabular}

Comparison of theoretical and experimental results for inclined sections' bearing capacity of RC beams without internal transverse steel reinforcement, strengthened by composite FRCM-system is determined by equation (11) given in table 3 .

Table 3

Results of bearing capacity determination for experimental samples

\begin{tabular}{|c|c|c|c|c|c|c|c|}
\hline \multirow{2}{*}{$\begin{array}{l}\text { Beam } \\
\text { code }\end{array}$} & \multicolumn{3}{|c|}{ Theoretical values } & \multicolumn{2}{|c|}{$\begin{array}{c}\text { Experimental val- } \\
\text { ues }\end{array}$} & \multirow{2}{*}{$\frac{V_{E d}}{V_{R d}}$} & \multirow{2}{*}{$\frac{V_{E d}^{a d d}}{V_{R d}^{a d d}}$} \\
\hline & $\begin{array}{c}V_{R d, c}, \\
\mathbf{k N}\end{array}$ & $\begin{array}{l}V_{R d, s}^{\text {add }} \\
\mathbf{k N}\end{array}$ & $\begin{array}{c}V_{R d}, \\
\mathbf{k N}\end{array}$ & $\begin{array}{c}V_{E d}, \\
\mathbf{k N}\end{array}$ & $\begin{array}{c}V_{E d}^{a d d}, \\
\mathbf{k N}\end{array}$ & & \\
\hline BO 1.1 & \multirow{2}{*}{81.6} & & 81.6 & 95 & - & 1.16 & - \\
\hline BSC 1.4 & & 34.6 & 116.2 & 137.5 & 42.5 & 1.18 & 1.23 \\
\hline
\end{tabular}

Design bearing capacity of $\mathrm{RC}$ samples, strengthened by composite system is equal to $116.2 \mathrm{kN}$, which is $18 \%$ less than experimental data. This result is within the error limits for non-strengthened samples. Calculation of bearing capacity obtained due to the composite system has shown the convergence of results about $23 \%$, which is also within the limits for non-strengthened samples, Thus, the proposed calculation methodology provides reliable possibilities for calculation subjected to shear force elements, strengthened with composite materials. However, this methodology needs further statistical improvement on the other researches' samples with another parameters.

\section{CONCLUSION}

Calculation of RC beams, subjected to shear force with the use of just the recommendations of valid norms shows sustainable overstatement while determination of bearing capacity. However, the use of refined values of $C_{R d, c}$ provides reliable convergence of the results within 16-29\% towards overstatement of experimental data. For determination of reinforced concrete beams shear strength it is reliable accuracy. In calculation of RC beams, strengthened by FRCM-system, taking as basis, the equations from valid norms, was obtained the similarity of $18 \%$, which is within the limits for control samples. The calculation of bearing capacity increase due to strengthening by FRCM-system showed the convergence of $23 \%$ towards overstatement of experimental results, which reveals possibility for use of this methodology while calculating of strengthened $R C$ beams, subjected to load. 


\section{REFERENCES}

Amadio, C., Macorini, L., Sorgon, S., Suraci, G., 2011. A novel hybrid system with RCencased steel joists, European Journal of Environmental and Civil Engineering, 15(10), 1433-1463. DOI:10.3166/EJECE.15.1433-1463.

Blikharskyy, Z., Selejdak, J., Blikharskyy, Y., Khmil, R., 2019. Corrosion of Reinforce Bars in RC Constructions, System Safety: Human - Technical Facility - Environment, 1, 277-283. DOI: 10.2478/czoto-2019-0036.

Blikharskyy, Z., Vashkevych, R., Vegera, P., Blikharskyy, Y., 2020. Crack Resistance of RC Beams on the Shear, Lecture Notes in Civil Engineering, 47, 17-24. DOI: 10.1007/978-3-030-27011-7_3.

Bobalo, T., Blikharskyy, Y., Kopiika, N., Volynets, M., 2020. Serviceability of RC Beams Reinforced with High Strength Rebar's and Steel Plate, Lecture Notes in Civil Engineering, 47, 25-33. DOI: 10.1007/978-3-030-27011-7_4.

Bobalo, T., Blikharskyy, Y., Vashkevich, R., Volynets, M., 2018. Bearing capacity of RC beams reinforced with high strength rebars and steel plate, MATEC Web of Conferences, 230, 02003. DOI: 10.1051/matecconf/201823002003

Concrete and reinforced concrete structures of heavy concrete. Design Rules: DSTU: B V.2.6-156: 2010. 2011. Minrehionbud of Ukraine, 118.

Concrete and reinforced concrete structures: DBN B.2.6 - 98: 2009. 2011. Minrehionbud of Ukraine 84.

Eurocode 2: Design of concrete structures - Part 1: General rules and rules for buildings (together with United Kingdom National Application Document). 1994 DD ENV 1992-1-1:1992, 194.

Eurocode 2: Design of concrete structures - Part 1-1: General rules for buildings. 2004. EN 1992-1-1:2004 (E), 225.

Ferrari, V. J., de Hanai, J. B., 2012. Flexural strengthening of reinforced concrete beams with carbon fibers reinforced polymer (CFRP) sheet bonded to a transition layer of high performance cement-based composite. Revista IBRACON de Estruturas e Materiais, 5(5), 596-626. DOI: 10.1590/S1983-41952012000500003

Krainskyi, P., Blikharskyy, Y., Khmil, R., Vegera, P., 2020. Crack Resistance of RC Columns Strengthened by Jacketing, Lecture Notes in Civil Engineering, 47, 195201. DOI: 10.1007/978-3-030-27011-7_25.

Krainskyi, P., Blikharskyy, Y., Khmil, R., Blikharskyy, Z., 2018. Experimental study of the strengthening effect of reinforced concrete columns jacketed under service load level, MATEC Web of Conferences, 183, 02008. DOI: 10.1051/matecconf/201818302008.

Lobodanov, M., Vegera, P., Blikharskyy, Z., 2020. Planning Experiment for Researching Reinforced Concrete Beams with Damages, Lecture Notes in Civil Engineering, 47, 243-250. DOI: 10.1007/978-3-030-27011-7_31.

Rossini, M., Spadea, S., Nanni, A., 2019. Pedestrian bridge as clarifying example of FRP-RC/PC design, ACI:Special Publication, 333, 96-118.

Selejdak, J., Blikharskyy, Y., Khmil, R., Blikharskyy, Z., 2020. Calculation of Reinforced Concrete Columns Strengthened by CFRP, Lecture Notes in Civil Engineering, 47, 400-410. DOI: 10.1007/978-3-030-27011-7_51.

Triantafillou, T., Matthys, S., et al., 2001. Externally bonded FRP reinforcement for $R C$ structures. Technical report, International Federation for Structural Concrete (FIB).

Vegera, P.I., Khmil, R. E., Blikharskyy, Z. Z., 2015. Optimization of the methodology of experimental research of inclined sections of reinforced concrete beams, Theory and Building Practice, 823, 38-43. (in Ukranian). 